\title{
Evaluation of Microbial Spoilage of Some Aquacultured Fresh Fish in Benin City Nigeria
}

\begin{abstract}
1WOGU, M.D. and 2MADUAKOR, C.C.

A microbiological study of organisms associated with spoilage of fresh fish samples collected from two ponds located in Benin City, Nigeria was carried out. Samples from the fish skin, gills and flesh were cultured in three media; nutrient agar, Maconkay agar and potato dextrose agar and on examination the presence of five bacteria species namely; Staphylococcus aureus, Klebsiella sp., Salmonella sp., Escherichia coli, Pseudomonas sp., and four fungi species namely; Aspergillis niger, Geotrichum sp., Rhizopus sp. and Pennicillium sp. was confirmed. The highest colony count was obtained from the skin samples in all the media. Antibiotic sensitivity pattern showed that all isolates were resistant to Gentamicin and Amoxicillin and the presence of the above pathogens in the fresh fish samples could pose a potential public health threat especially to consumers. It is recommended that better handling and processing methods should be adopted to reduce or eliminate health risk to fresh fish consumers.
\end{abstract}

\section{Introduction}

$$
\text { This paper presents a }
$$
determine micro organisms associated with fresh fish spoilage in aquacultured fresh fish in Benin City, Edo State Nigeria. In recent times there has been renewed effort in fish production especially in artificial (concrete and plastic) ponds as a way of augmenting the protein requirement of the increasing human population in urban areas with the prohibitive price of beef and other animal protein sources. Fish along with shrimps, crabs, lobsters, shellfish etc. are generally categorized as seafood (Gram and Huss, 2001). Seafoods may harbor a number of biohazards as well as chemical contaminations such as biogenic amines, biotoxins, pathogenic bacteria and viruses (Gram et al., 2000 and Ashie et al., 2001).

The last two decades have seen appreciable increase in global fish trade and the need to enforce safety standards and regulations on imported consignment especially from developing nations fraught with unacceptable levels of microbiological contamination (EU, 1998 and ICMSF, 2005). Contamination concern has been on high loads of unsuspected spoilage by microorganisms like Salmonella sp., Staphylococcus aureus, Pseudomonas aeruginosa and Escherichia coli (Bramsnacs, 1999 and Gram et al., 2000). Spoilage patterns of fish have been well documented (Botta, 1995 and Doyle 2007) and usually varied according to species, feeding habits, seasonality, age of fish and also geographical location (Howgate 1982).

Fresh fish spoilage and high perishability are primarily due to large amount of non-protein nitrogen (like free amino acids), volatile nitrogen bases (ammonia, creatine, taurine, uric acid, carnosine and histamine) which support post mortem bacteria growth (Connell and Shewan, 1990; May and Ward, 1997 and Jay et al., 2005). Fish also possess a neutral to slightly acidic $\mathrm{pH}$ and high moisture content which favor growth of a wide range of microbes coupled with their poikilothermic nature (Herbert et al., 1997). Fish spoilage essentially can be attributed to three main factors namely; microbial, enzymatic or autolytic and chemical spoilage (oxidative rancidity) of which microbiological contamination has been noted as the main cause of fish deterioration. Initial microflora on the surface of the fish is directly related to the surrounding aquatic environment while the bacterial flora in the gastrointestinal tract corresponds to the type of condition of the fish (Liston, 1980). According to Herbert et al., (1997), intrinsic and extrinsic factors determine the initial bacterial contamination.

In Nigeria fish is the preferred source of much desired animal protein compared to poultry, beef, mutton, pork and veal. It is comparatively cheaper and highly acceptable, with little or no religious bias, which gives it an advantage over pork or beef (Johnson et al., 1994 and Feldhusen, 2000). Currently there is scarcity of information on microbial spoilage fresh fish especially in Nigeria. This study therefore aims to identify the microorganisms associated with spoilage of aquacultured fish, determine the factors affecting fish spoilage and also obtain information on the incidence and distribution of microbial spoilage organisms of fresh fish samples. 


\section{Methodology}

Three species of commonly cultured fresh fish samples (Clarias gariepinus, $C$. heterobranchus and Tilapia sp.) were collected from two locations in Benin City; Benson Idahosa University fish farm and the Graduate Farmers Farm at Aduwawa. The fresh fish species were killed and macerated in a mortar and one gram of fish tissue was dissolved in test tube containing $9 \mathrm{ml}$ of sterilized distilled water to obtain a solution. Serial dilution up to $10^{-5}$ was carried out on extracts from the skin, gill and flesh. I ml of each of the samples from the $10^{-5}$ was transferred into petri dishes in replicates of two after which nutrient agar was added. This procedure was repeated for Maconkay and potato dextrose agar culture media respectively. The dishes were rotated by hand in a swirling motion so that the inoculum was uniformly dispersed in the medium. The agar was allowed to solidify and incubated at $37^{\circ} \mathrm{C}$ for 24 hours. Microbial colonies counts were taken using a digital colony counter (LABTECH) after incubation for the identified bacteria and fungi species. Colonies of each suspected bacteria species were subcultured in fresh nutrient agar plates.

Biochemical tests like catalase, coagulase, oxidase, indole, urease, citrate and methyl red were carried out as well as morphological characteristics like Gram staining and motility test were used to properly confirm identification of microbial isolates.

\section{Results}

\section{Microbial Colony Count}

The result of the total microbial colony counts expressed in cfu x $10^{5}$ obtained from three separated media (Nutrient agar, Maconkay agar and potato dextrose agar) and cultured fresh fish samples obtained from the skin, gill and flesh is shown in Table 1. Higher values were recorded in nutrient agar medium in all parts of the fish cultured. Mean microbial counts ranged from a minimum count of 112 cfux $10^{5}$ recorded in the flesh sample to maximum value of 215 cfux $10^{5}$ recorded in the skin sample. For Maconkay agar the values ranged from 52.5 to 111.5 cfux $10^{5}$ and 6 to 25 cfux $10^{5}$ in potato dextrose agar. The trend of variation in colony count of the various parts of the fish sampled showed highest microbial load on the fish skin followed by gill and then the flesh. Generally, microbial load in the culture media varied in the order of Nutrient agar > Maconkay agar > Potato dextrose agar and in this order the highest mean value in each succeeding medium was less than the lowest mean value of the medium preceding it. Morphological and Biochemical Characteristics of Isolates

Table 2 showed the result of morphological and biochemical criteria used in characterization and identification of the bacteria species isolated. Microscopic observation revealed details of cultural characteristics of suspected bacteria and result of biochemical test confirmed the presence of Staphylococcus aureus, Klebsiella sp., Salmonella sp., Escherichia coli and Pseudomonas sp.

Cultural and Morphological Characteristics of Fungal Isolates

Based on the pigmentation of the spores, nature of the mycelia and spore formers the following fungal species were observed from the fish samples; Aspergillus niger, Geotrichum sp. Rhizopus sp. Penicillium sp (Table 3).

\section{Discussion}

The results from this study revealed the presence of four fungal species namely; Aspergillis niger, Geotrichum sp., Rhizopus sp. and Pennicillium sp. and five bacterial species namely; Staphylococcus aureus, klebsiella sp. Salmonella sp., Escherichia coli and Pseudomonas sp. and these are the major pathogens associated with post-harvest fish spoilage. This finding is in agreement with previous findings by Gram and Huss (2001), who reported that these organisms were the major causes of microbial spoilage of fresh fish after capture and the microbial count on the different media suggests contamination. Higher microbial counts in the skin samples comparative to the gill and flesh may be attributable to handling during harvest and processing and high Escherichia coli in all the samples may be due to its ubiquitous nature as it could be found in almost all environment including human skin, water and air during processing. This result corroborated that of Majeed and MacRae (1991) who observed that most of the bacteria flora associated with spoilage of fish were Gram negative rod bacilli such as E. coli, Salmonella sp. and Pseudomonas sp. The total bacterial count on fish rarely indicate the quality of the fish but it gives an indication of the risk of spoilage induced since each of these organisms had different ways of affecting health conditions of 
consumers of such contaminated fish (Gram et $a l ., 2000)$. It is generally accepted that fish with microbial load of $>10^{6} \mathrm{cfu} / \mathrm{ml}$ is likely to be at the stage being unacceptable from the microbiological point of view and unfit for human consumption (Cheesbroughl, 2000).

Conversely, Miller et al., (1973) observed that not all bacteria present on fresh fish are spoilers but there are certain active spoilers which are the major pathogens on fish spoilage. These bacteria have the ability to reduce trimethylamine and produce hydrogen sulphide from sodium thiosulphate as asecondary metabolite that constitute fresh fish spoilage. The presence of Klebsiella and Salmonella spp. in the fresh fish samples is an indication that the water used for processing was faecally contaminated. Pseudomonas sp. was the fourth most common bacteria isolated and the observation in the present study was low compared to previous reports by Gram et al., (2000) owing to the fact that during storage at $0^{\circ} \mathrm{C}$ they had fewer isolates. Therefore Pseudomonas sp. is the major pathogen associated with fresh fish spoilage during refrigeration (Gram, 1993). The presence of Staphylococcus aureus a normal flora of skin and mucous membrane of humans can be attributed to human contact during handling and processing (Dalgaard et al., 2006). Staphylococcus aureus produces a variety of extra cellular enzymes and toxins that have been found to be responsible for food poisoning and can rapidly develop resistance

\section{References}

Ashie, I.N.A., Smith, J.P. and Simpson, B.K. (1996), Spoilage and shelf life extension of fresh fish and shell fish. Critical Reviews in Food Science and Nutrition, 36, 87 - 121.

Botta, J.R. (1995), Evaluation of seafood freshness quality $\mathrm{VCH}$ Publishing International, England. 54pp.

Bramsnacs, F. (1999), Handling of fresh fish. Borgstrom, C. (ed.). Fish as food. Arnord publishers. London.

Cheesbrough, M. (2000), District laboratory practice in Tropical countries. Cambridge University press, United Kingdom. 416pp.

Connell, J.J. and Shewan, J.M. (1990), Past, present and future of fish science. In. Connell, J.J. (ed.). Advances in fish science and technology. Jubillee Conference of Tommy Research, Oxford. pp $22-27$.

Dalgaard, P., Samieia, N. and Emborg, J. (2006), Biogenic amine formation and to many antimicrobial agents and pose therapeutic problems (Thrower, 2000).

Table 4 shows antibiotic sensitivity pattern of the bacteria isolates from the fresh fish samples using the agar disc diffusion method with Augmentin, Tetracyclin, Gentamicin, Nitrofuranton, Cotrioflaxacin, Amoxicillin and Chloroamphenicol. Gentamicin was found to be most sensitive to all bacteria isolates. Maximum resistance of the bacteria isolates was found in Amoxicillin. However, infective dose was dependent on individual susceptibility and the onset and severity of disease may depend on quantity of toxin in the fish and quantity of fish ingested.

\section{Conclusion}

The presence of these bacterial and fungal isolates in fresh fish spoilage is indicative of public health risk in contacting diseases associated with these organisms. Compliance with standard microbiological measures to prevent contamination by these organisms becomes very necessary and should be ensured. Lack of proper storage facility after capture and insanitary conditions during processing are the major sources of contamination identified in this study. In view of the findings of this research work it is therefore recommended that good hygienic conditions and use of clean water during processing should be strictly adhered to. After harvest, fresh fish should be properly stored at low temperatures so as to inhibit survival of mesophilic bacteria

microbial spoilage in chilled garfish (Belone belone) - effect of modified atmosphere packaging and previous frozen storage, Jounal of Applied Microbiology, 101, 80 - 95.

Doyle, E.M. (2007), Microbial food spoilage losses and control strategies. Food Research Institute. University of Wisconsin-Madison.

European Union (1998), Assessment of fish and fish products. Weekly Report,17, 13 -14.

Feldhusen, F. (2000), The role of sea food bacterial food-borne diseases. Microbes and Infections, 2, 1651 - 1660.

Gram, L. and Huss, H.H. (2001), Microbiological spoilage of fish and fish products. International Journal of Food Microbiology, 33, 121 - 137.

Gram, L., Oundo, J.O. and Bon, J. (2000), Shelf life of fish depends on storage temperature and initial bacteria load. Tropical Science, 25, 28 - 30. 
Herbert, R.A., Hendrie, M.S., Gibson, D.M. and Shewan, J.M. (1997), Bacteria active in the spoilage of certain sea foods. Journal of Applied Bacteriology, 34, 41 - 50.

Howgate, P.F. (1989), Quality assessment and quality control. In: Fish Handling and processing. Atkin, A. Merit, I.M., and Windsor, M.I. (eds.). Edinburgh Publishers. pp $13-17$.

International Commission on Microbiological Specifications of Foods. (2005), Fish and fish products Microorganisms in fish products 6: Microbial ecology of food commodities. Kluwer Academic/Plenum Publishers. New York. pp. $172-249$.

Jay, J.M., Loessner, M.J. and Golden, D.A. (2005), Modern Food Microbiology. Springer, Washington.

Johnson, W.A., Nicolas, F.J. and Roger, A. (1994), Freezing and refrigerated storage in fisheries. Stroud Series, FAO Fisheries Technical paper T340 143pp.

Liston, E. (1980), Microbiology in fisheries. In. Connell, J.J. (ed.). Advances in fish science and technology. Jubillee Conference of Tommy Research, Oxford. pp. $18-21$.

Majeed, K.N. and MacRae, I.C. (1991), Experimental evidence of toxin production by Aeromonas hydrophila and Aeromonas sobria in meat extract at low temperature. International Hournal of Food Microbiology, 12, $181-188$.

May, B.K. and Ward, D.R. (1997), Microbiology of finfish and finfish processing. In. Ward, D.R. and Hackney, C. (eds.). Nostrad Reinhold. New York. pp. $21-27$.

Miller, A., Scanlan, R.A., Lee, J.S. and Libbey, L.M. (1973), Volatile compounds produced in sterile fish muscle (Sabastes melanops) by Pseudomonas putrefaciens, Pseudomonas fluorescens, and an Achromobacter species. Applied Microbiology, 26, $18-21$.

Thrower, S.J. (2000), Handling practices on onshore fishing vessels. Effects on the quality of finfish products. Food Research, 47, $50-$ 55 .

Table 1 Total microbial count from skin, gill and flesh of the fresh fish samples

\begin{tabular}{|l|l|l|l|l|l|l|l|l|l|}
\hline \multirow{2}{*}{ SAMPLES } & \multicolumn{9}{l|}{ COLONY COUNT $\left(\mathbf{X 1 0}^{\mathbf{5}} \mathbf{C f u m l}^{-\mathbf{1}}\right)$} \\
\cline { 2 - 10 } & Nutrient Agar & Mean & \multicolumn{2}{l|}{ Maconkay Agar } & Mean & \multicolumn{2}{l|}{ Potato Dextrose Agar } & Mean \\
\hline Skin & 216 & 214 & 215 & 121 & 102 & 111.5 & 26 & 24 & 25 \\
\hline Gill & 189 & 179 & 184 & 87 & 62 & 74.5 & 11 & 4 & 7.5 \\
\hline Flesh & 137 & 87 & 112 & 75 & 30 & 52.5 & 9 & 3 & 6 \\
\hline
\end{tabular}


Table 2 Morphological and Biochemical Characteristics of bacterial isolates

\begin{tabular}{|c|c|c|c|c|c|c|c|c|}
\hline Test & \multicolumn{8}{|l|}{ Isolates } \\
\hline $\begin{array}{l}\text { CULTURAL } \\
\text { CHARACTERISTICS }\end{array}$ & 1 & 2 & \multicolumn{2}{|c|}{3} & \multicolumn{2}{|c|}{4} & \multicolumn{2}{|l|}{5} \\
\hline Cell form & Circular & Circular & \multicolumn{2}{|c|}{ Circular } & \multicolumn{2}{|c|}{ Circular } & \multicolumn{2}{|c|}{ Circular } \\
\hline Colony margin & Entire & Flat & \multicolumn{2}{|c|}{ Entire } & \multicolumn{2}{|c|}{ Entire } & \multicolumn{2}{|c|}{ Undulate } \\
\hline Elevation & Convex & Convex & \multicolumn{2}{|c|}{ Convex } & \multicolumn{2}{|c|}{ Flat } & \multicolumn{2}{|c|}{ Flat } \\
\hline Texture & Smooth & Mucoid & \multicolumn{2}{|c|}{ Mucoid } & \multicolumn{2}{|c|}{ Smooth } & \multicolumn{2}{|c|}{ Rough } \\
\hline Pigmentation & Cream & Pinkish & \multicolumn{2}{|c|}{$\begin{array}{l}\text { Light } \\
\text { cream }\end{array}$} & \multicolumn{2}{|c|}{ White } & \multicolumn{2}{|c|}{ Cream } \\
\hline Optical Characteristics & Opaque & Opaque & \multicolumn{2}{|c|}{ Opaque } & \multicolumn{2}{|c|}{ Opaque } & \multicolumn{2}{|c|}{ Opaque } \\
\hline \multicolumn{9}{|l|}{ Morphology } \\
\hline Gram staining & $+\mathrm{ve}$ & -ve & & \multicolumn{2}{|l|}{-ve } & \multicolumn{2}{|l|}{-ve } & -ve \\
\hline Cell shape & Cocci & Rod & & \multicolumn{2}{|l|}{ Rod } & \multicolumn{2}{|c|}{ Rod } & Rod \\
\hline \multicolumn{9}{|l|}{ BIOCHEMICAL } \\
\hline Catalase & + & + & & \multicolumn{2}{|l|}{+} & \multicolumn{2}{|l|}{+} & - \\
\hline Coagulase & + & - & & \multicolumn{2}{|l|}{-} & \multicolumn{2}{|l|}{-} & - \\
\hline Oxidase & - & - & & \multicolumn{2}{|l|}{-} & - & & + \\
\hline Indole & - & - & & + & & + & & - \\
\hline Urease & - & - & & - & & - & & - \\
\hline Citrate & - & + & & + & & - & & + \\
\hline Methyl red & + & + & & + & & + & & + \\
\hline FERMENTATION & & & & & & & & \\
\hline Glucose & $\mathrm{A} / \mathrm{G}$ & A & & $\mathrm{A} / \mathrm{G}$ & & $\mathrm{A} / \mathrm{G}$ & & - \\
\hline Lactose & - & + & & - & & $\mathrm{A} / \mathrm{G}$ & & - \\
\hline Sucrose & $\mathrm{A} / \mathrm{G}$ & A & & $\mathrm{G}$ & & A & & $\mathrm{G}$ \\
\hline Suspected organism & $\begin{array}{l}\text { Staphylococcus } \\
\text { aureus }\end{array}$ & Klebsiello & & $\begin{array}{l}\text { Salm } \\
\text { sp. }\end{array}$ & & $\begin{array}{l}\text { Escl } \\
\text { coli }\end{array}$ & chia & $\begin{array}{l}\text { Pseudomonas } \\
\text { sp. }\end{array}$ \\
\hline
\end{tabular}

$+=$ positive,$-=$ negative, $\mathrm{A}=$ acid production, $\mathrm{A} / \mathrm{G}=$ acid and gas production, $\mathrm{G}=$ gas production

Table 3 Cultural and Morphological Characteristics of Fungal Isolates

\begin{tabular}{|l|l|l|l|l|l|}
\hline Fungal species & Spore color & Stolon & Surface & Hyphae & Spore-former \\
\hline Aspergillus niger & Brownish & Absent & Fluffy & Septate & Conidiophore \\
\hline Geotrichum sp. & White & Absent & Colon-like & Non-septate & Chlamydophore \\
\hline Rhizopus sp. & Black & Absent & Fluffy & Non-septate & Sporangiophore \\
\hline Penicillium sp. & Green & Absent & Colon-like & Septate & Conidia \\
\hline
\end{tabular}

Table 4 Antibiotics Susceptibility Test

\begin{tabular}{|l|l|l|l|l|l|}
\hline \multirow{2}{*}{ Antibiotics } & \multicolumn{2}{l|}{ Test Isolates } \\
\cline { 2 - 6 } & $\begin{array}{l}\text { Escherichia } \\
\text { coli }\end{array}$ & $\begin{array}{l}\text { Staphylacoccus } \\
\text { aureus }\end{array}$ & $\begin{array}{l}\text { Salmonella } \\
\text { sp. }\end{array}$ & $\begin{array}{l}\text { Pseudomonas } \\
\text { sp. }\end{array}$ & $\begin{array}{l}\text { Klebsiella } \\
\text { sp }\end{array}$ \\
\hline Augmentin $(\mathrm{mm})$ & $25(\mathrm{R})$ & $10(\mathrm{~S})$ & $8(\mathrm{~S})$ & - & $6(\mathrm{~S})$ \\
\hline Tetremycin $(\mathrm{mm})$ & $4(\mathrm{~S})$ & $25(\mathrm{R})$ & $22(\mathrm{R})$ & $30(\mathrm{R})$ & $19(\mathrm{R})$ \\
\hline Gentamicin $(\mathrm{mm})$ & $28(\mathrm{R})$ & $38(\mathrm{R})$ & $18(\mathrm{R})$ & $27(\mathrm{R})$ & $16(\mathrm{R})$ \\
\hline Nitrofuranton $(\mathrm{mm})$ & $15(\mathrm{R})$ & $19(\mathrm{R})$ & $2(\mathrm{~S})$ & $5(\mathrm{~S})$ & $7(\mathrm{~S})$ \\
\hline Cotrioflaxacin $(\mathrm{mm})$ & $20(\mathrm{R})$ & $4(\mathrm{~S})$ & $9(\mathrm{~S})$ & 25 & $2(\mathrm{~S})$ \\
\hline Amoxicillin $(\mathrm{mm})$ & $10(\mathrm{~S})$ & $4(\mathrm{~S})$ & $2(\mathrm{~S})$ & $10(\mathrm{~S})$ & $7(\mathrm{~S})$ \\
\hline Chloroamphenicol $(\mathrm{mm})$ & $3(\mathrm{~S})$ & $7(\mathrm{~S})$ & $5(\mathrm{~S})$ & $10(\mathrm{~S})$ & $24(\mathrm{R})$ \\
\hline
\end{tabular}

$(\mathrm{R})=$ Resistant (above 12mm), $\mathrm{S}=$ Susceptible (below 12mm) 